\title{
AL-A'RAF
}

Jurnal Pemikiran Islam dan Filsafat

\section{KONSEP HOMINISASI DAN HUMANISASI MENURUT DRIYARKARA}

\author{
Asep Rifqi Abdul Aziz \\ Fakultas Filsafat, Pascasarjana UGM Yogyakarta
}

\begin{abstract}
Abstrak
Keywords:

Globalization, Hominization, Humanization and.
\end{abstract}

\begin{abstract}
Changing of epoch with all brought payload is truly inevitable. Progress will continue to walk along with the growth of the human being's intelligence. The rapid of the globalization today is likely giving more problems faced by human being. Indeed, globalization does not fully bring negative effect, as long as human beings are able to utilize its product wisely, including in the educational sectors. This article tries to offer an alternative perspective on how to overcome the various problems in the life of society nowadays; i.e. through the idea of Driyarkara, on hominization and humanization: an educational philosophy to promote human's awareness to humanize human being.
\end{abstract}




\section{Pendahuluan}

Manusia tidak dengan sendirinya bersifat manusiawi sesudah kelahirannya. ${ }^{1}$ Kelahiran menjadi langkah awal manusia berkenalan dengan dunia, walaupun tidak sepenuhnya sadar, setidaknya manusia memiliki pengakuan akan eksistensinya. Artinya, wujudnya sebagai entitas yang terdiri dari tulang yang dibungkus daging dan kulit dengan segala ciri yang dimiliki, manusia pada umumnya mampu dikenali dan diterima oleh manusia lain. Hal itu menunjukan bahwa manusia 'baru' siap untuk menghadapi dunia dengan segala dinamikanya. Ironisnya, kelahiran saja tidak cukup menjadikannya manusiawi, terdapat aspek lain yang tidak kalah penting untuk menjadikan manusia sebagai sosok yang manusiawi, yaitu aspek pendidikan.

Pendidikan dimulai sejak manusia dilahirkan. Pernyataan itu tidak sepenuhnya bisa dibenarkan, mengingat adanya asumsi lain yang layak dipertimbangkan bahwa pendidikan dimulai semenjak dalam kandungan. Terlepas dari perbedaan waktu, kedua asumsi tersebut menunjukan bahwa pendidikan merupakan bagian tidak terpisahkan dari manusia sepanjang zaman. ${ }^{2}$. Dalam arti paling mendasar, pendidikan didefinisikan sebagai proses memanusiakan manusia, dalam artian manusia yang didudukan sebagai makhluk hidup dengan segala keunikannya serta tidak mereduksinya menjadi objek yang tidak memiliki diri. Dengan kata lain, pendidikan sebagai proses pembentukan manusia yang berbudaya. ${ }^{3}$

Gagasan memanusiakan manusia juga diperjuangkan oleh Driyarkara, dengan tidak mereduksinya ke dalam paradigma obyektifitas, rigid, dan tertutup. Di satu sisi, manusia berbentuk materi seperti makhluk

${ }^{1}$ Driyarkara, dkk. (ed), Karya Lengkap Driyarkara; Esai-Esai Pemikiran yang Terlibat Penub dalam Perjuangan Bangsanya, (Jakarta: Gramedia, 2006), 264.

${ }^{2}$ Suparlan Supartono, Filsafat Pendidikan, (Jogyakarta: Ar-Ruzz Media, 2008), 77.

${ }^{3}$ Gerald L. Gutek, Philosophical and Ideological Perspectives on Education, (New Jesey: Prentice Hall, 1988), 4. 
lainnya. Di sisi lain manusia adalah persona yang memiliki kepribadian sebagai identitas khusus, tidak dimiliki makhluk lain. Dengan personanya, manusia berbudaya membangun relasi dengan yang lain. Relasi tersebut tidak akan mencapai kulminasi idealnya tanpa pendidikan. Pada intinya, Driyarkara ingin mengungkapkan bahwasanya pendidikan merupakan proses perubahan ganda: pertama perubahan dalam diri manusia sendiri yang sebut sebagai eksistensia. Kedua di dalam pendidikan, proses perubahan diri haruslah menyatu dengan perubahan masyarakat serta budaya. ${ }^{4}$

Perubahan zaman, selain memiliki keunggulan yang patut untuk dibanggakan juga memiliki dampak negatif yang setia merongrong. Namun dampak negatif itu tidak secara eksplisit dapat diserap, maka hanya sebagian orang yang mempu mengidentifikasi dan menyadarinya. Moderenisasi, begitulah kebanyakan orang menyebutnya, merambah hampir ke segala lini: dari bidang ekonomi, sosial, politik, ideologi, kultur-termasuk pendidikan. Meskipun dalam konteks historisnya moderenisasi muncul di belahan dunia Barat, namun berangkat dari sanalah moderenisasi mulai merambah hampir keseluruh penjuru dunia, sampai dengan Indonesia. Ide pembebasan-yang menjadi creedo moderenisasi-menjadi basis tegaknya ekonomi melalui sistem kebutuhan-kebutuhan terbuka. ${ }^{5}$ Artinya, suatu masyarakat yang tidak dapat mengikuti arus gerak moderenisasi, yang ditandai oleh rasionalitas, logika ekonomi, teknologi, dan ideologi akan menjadi hidangan untuk memenuhi kebutuhan masyarakat lain yang lebih modern. Begitupun dengan ruang pendidikan.

Ruang pendidikan dikatakan moderen apabila mengikuti logika ekonomi, atau katakanlah logika pasar. Sederhananya, institusi pendidikan yang memiliki nilai jual akan menjadi primadona yang banyak diminati. Sebaliknya, institusi pendidikan yang tidak memiliki nilai jual, seketika gulung tikar. Pada titik paling radikal, potret pendidikan seperti ini bisa

${ }^{4}$ Driyarkara, dkk. (ed), Karya Lengkap Driyarkara; Esai-Esai Pemikiran yang Terlibat Penuh dalam Perjuangan Bangsanya, (Jakarta: Gramedia, 2006), 269.

${ }^{5}$ F. Budi Hardiman, Melampan Postivisme dan Modernitas, (Yogyakarya: Penerbit Kanisius, 2003), 76. 
dikatakan komodifikasi atau industrialisasi pendidikan. Makalah ini akan mencoba memberi jawaban atas problem peralihan dalam wilyah pendidikan yang dipengaruhi oleh perbahan zaman.

\section{Mengenal Sosok Driyarkara}

Driyarkara lahir di lereng Pegunungan Menoreh, Jawa Tengah, pada 13 Juni 1913, dan meninggal pada 11 Februari 1967 di usia 53 tahun 8 bulan. Driyakarya lahir di desa Kedunggubah, sebelah Timur Puwerejo, Kedu, Jawa Tengah, dengan nama Soehirman dan biasa dipanggil Djenthu, yang berarti kekar dan gemuk. Soehirman berganti nama menjadi Driyarkara pada tahun 1935, ketika masuk Girisonta dan mulai hidup baru dalam Serikat Jesus, yang anggotanya biasa dipanggil Jesuit. Driyarkara merupakan anak bungsu keluarga Atmasendjaja dari empat bersaudara. Kakaknya terdiri dari dua perempuan dan satu laki-laki.

Perjalana pendidikan Driyakara dimulai dari sekolah Volkschool dan Vevolgschool di Cangkrep, lalu dilanjutkan dengan HIS (Hollandsch Inladsche School) di Purworejo dan Malang. Jarak yang harus ditempuh dari rumahnya ke Cangkrep sekitar $5 \mathrm{~km}$, sedangkan ke Purworejo $8 \mathrm{~km}$. Semuanya ia tempuh dengan berjalan kaki. Wirjasendjadja, lurah Desa Kedunggubah dan juga paman Driyakara memiliki peran penting dalam perjalanan pendidikan formalnya. Wirjasendjadja selalu mendukung Driyakara untuk terus belajar.

Tahun 1929 Driyakara masuk Seminari Menengah, Sekolah Menengah khusus calon imam Katolik setingkat dengan SMP dan SMA, dengan Program Studi Humaniora Gymnasium di Negeri Belanda. Setelah menyelesaikan Sekolah Menengah di Seminari, Driyakara mulai menempuh pendidikan tinggi untuk calon imam bergabung dengan Serikat Jesus. Selama dua tahun mempelajari ascetika (kehidupan rohani), satu tahun humaniora (bahasa Latin, Yunani kuno serta sejarah kebudayaan Timur dan Barat) guna persiapan untuk studi filsafat. Semuanya dijalani Driyakara di Girisonta. Antara tahun 1935-1941, Driyakara menghabiskan 
waktunya untuk belajar filsafat di Sekolah Tinggi Filsafat di Yogyakarta, yang pada waktu itu disebut Ignatius College.

Tahun 1942-1943 Driyakara belajar teologi di Kolose Muntilan bersama rekan-rekannya sesama Jesuit, sebelum Kolose Muntilan ditutup oleh Jepang. Setelah Kolose tersebut ditutup oleh Jepang, Driyakara dipanggil ke Yogyakarta untuk bergabung dengan misionaris Belanda, termasuk didalamnya dosen-dosen filsafat, untuk masuk interniran. Driyakara diamanati untuk mengajar filsafat di Seminari Tinggi Yogyakarta. Disamping menjalankan tugasnya sebagai dosen, Driyakara juga acapkali belajar teologi secara otodidak sebagai persiapan untuk di tahbiskan menjadi imam Katolik. Driyakara ditahbiskan pada tanggal 6 Januari tahun 1947 oleh Mgr. Soegijapranata S.J. yang berkedudukan di Semarang dan membawahi umat Katolik di sebagian Jawa Tengah dan seluruh Daerah Istimewa Yogyakarta.

Tanggal 24 Juli 1947, Driyakara ditugaskan oleh Mgr. Soegijapranata dan pimpinan Serikat Jesus di Indonesia untuk menyelesaikan studi teologinya di Maastricht, Belanda. Penugasan itu dilatarbelakangi anggapan bahwa dengan diselenggarakannya perjanjian Linggarjati pada tanggal 15 November 1946, sengketa antara Republik Indonesia dan Kerajaan Belanda sudah selesai. Meski pada kenyataannya belum juga usai. Dengan berat hati, Driyakara berangkat ke Belanda untuk menunaikan tugasnya. Bukan atas dasar 'tega' terhadap Indonesia, namun lebih pada ketaatan. Tahun 1949, Driyakara menyelesaikan studi teologinya, dilanjutkan dengan studi tentang kehidupan rohani di Drogen, dekat Gent, Belgia. Kemudian pada tahun 1950-1952, Driyakara melanjutkan studi Doktoralnya di bidang filsafat di Roma, tepatnya di Universitas Gregoriana, dengan disertasi doktoral berjudul Participationis Cognitio In Existential Dei Percipienda Secundum Malebranche Utrum Partem Hebeat (Peranan Pengertian Partisipasi dalam Pengertian tentang Tuhan Menurut Malebranche'.

Setelah menyelesaikan program studi Doktoralnya, Driyakara kembali ke Indonesia dan diangkat menjadi pengajar filsafat di Ignatius 
College, Yogyakarta. Pada tahun 1955-1956, Driyakara diangkat menjadi pimpinan PTPG (Perguruan Tinggi Pendidikan Guru) Sanata Dharma, Yogyakarta, yang selanjutnya berubah menjadi FKIP (Fakultas Keguruan dan Ilmu Pendidikan), di mana Driyakara tetap menjadi Dekannya. Seiring perjalanan waktu, FKIP pun berubah menjadi IKIP (Institut Keguruan dan Ilmu Pendidikan), namun tidak ada perubahan dalam struktur. Driyakara tetap menjadi Rektor sampai akhir hayatnya. Bahkan, selain menjadi Rektor sejak awal tahun 1960, Driyakara juga menjadi Guru Besar Luar Biasa di Univertisat Indonesia dan Hassanudin.

Selain di dunia akademis, Driyakara juga aktif di dunia politik. Pada tahun 1960 dia diangkat menjadi anggota MPRS. Kemudian pada tahun 1965 dia menjadi salah satu anggota Dewan Pertimbangan Agung (DPA). Tapi sayang sejak bulan januari 1965, dewan ini tidak pernah mengadakan rapat. Hal itu berimbas pada fungsinya sebagai aparatus Negara yang minim fungsi. Akhirnya, setelah berbagai macam peristiwa terlewati, sekitar tanggal 11 Maret 1966, Presiden membentuk DPA(S) baru. Dia salah satu anggota dari 18 orang yang menentang berdirinya dewan tersebut secara resmi, dengan alasan selama Driyakara menjabat sebagai anggota DPA tidak pernah dimintai nasihat. Selain itu, pendirian DPA(S) tidak memenuhi prosedur yang berlaku.

\section{Manusia menurut Driyarkara}

Driyakara termasuk filsuf yang mengakui adanya unsur badan dan jiwa dalam diri manusia, jiwa sebagai prinsip rohani dan badan sebagai prinsip jasmani (Driyakara, 1978:11). Namun, untuk memahami bagaimana badan dan jiwa menurut Driyakara memang tidak mudah. Menurutnya, hal yang pertama kali harus disadari bahwa manusia adalah makhluk yang berbadan, dan mampu melakukan aktivitas sehari-hari menggunakan badannya, seperti berjalan, makan, olahraga dan lain sebagainya. Berkat badannya manusia menjalankan aktivitasnya tanpa gangguan. Sedangkan cacat badan mengakibatkan seseorang terhalang untuk melakukan segala 
hal. Ketika salah satu panca indra manusia tidak berfungsi dengan baik, maka kemampuan manusia untuk menangkap realitas pun berkurang. Begitulah manusia yang berbadan. ${ }^{6}$

Badan yang menjadi salah satu unsur dalam diri manusia pada hakikatnya sama seperti barang-barang materil lainnya. Secara biologis, badan manusia dan badan kera sama, tidak kebal akan panca indra. Sifatsifat yang melekat pada badan manusia sama halnya dengan barangbarang lainnya. Dengan kata lain, badan manusia berada bersama barangbarang lainnya, ia mengambil bagian dari kosmos, terlempar, dan melekat. Lantas apa bedanya? Menurut Driyakara, kalaulah manusia hanya dilihat dari badannya, bisa dibilang paradigma itu belum lengkap. ${ }^{7}$ Pandangan yang mengungkapkan manusia hanya dari segi badannya, hanya mampu menampung pertanyaan tentang 'apa'. Padahal manusia itu bukan hanya 'apa', tapi juga 'siapa'.

Driyakara berpendapat, mengenai pertanyaan siapa manusia bukanlah pertanyaan yang mudah untuk dijawab. Dilihat dari tata bahasa, apa dan siapa hanya memiliki perbedaan yang sangat tipis. Perbedaannya hanya pada suku kata 'si'. Ironisnya, perbedaan suku kata tersebut menunjukan pada dunia yang sama sekali berlainan. Tidak tepatlah orang mengatakan 'siapa' pada seekor kera ataupun kucing. Hal ini menunjukan, pertanyaan 'siapa', hanya pantas disematkan pada manusia. ${ }^{8}$ Secara implisit, pertanyaan siapa dengan memproblematisir dari permasalahan tata bahasa, memiliki konotasi bahwa selain yang berbentuk materi, manusia memiliki unsur lain sebagai diferensiasi antara manusia dan makhluk lainnya, seperti monyet, kucing, dan tumbuhan.

Driyakara menggaris bawahi credo, bahwa manusia adalah pribadi (person). Dalam pribadi manusia yang pertama kali kita fahami, manusia

${ }^{6}$ Driyarkara, Driyarkara tentang Manusia, (Yogyakarta: Yayasan Kanisius, 1978), 10.

${ }^{7}$ Driyarkara, dkk. (ed), Karya Lengkap Driyarkara; Esai-Esai Pemikiran yang Terlibat Penuh dalam Perjuangan Bangsanya, (Jakarta: Gramedia, 2006), 35.

${ }^{8}$ Driyarkara, dkk. (ed), Karya Lengkap Driyarkara; Esai-Esai Pemikiran yang Terlibat Penuh dalam Perjuangan Bangsanya, 35 
memiliki dirinya sendiri. Tidak ada otoritas apapun yang memiliki manusia kecuali dirinya sendiri, walaupun dalam konteks perbudakan. Driyakara dalam menjelaskan istilah 'memiliki' tidak mengandaikan kepemilikan yang 'terlepas'. Dalam arti, antara pemilik dan yang dimiliki bukanlah dua entitas yang berbeda. Keduanya adalah satu. Ia menggunakan istilah 'bersemayam'. Manusia bersemayam dalam diri sendiri. ${ }^{\text {' }}$

Merujuk pada kamus besar bahasa Indonesia, bersemayam diartikan sebagai duduk atau tinggal. Misalnya, baginda bersemayam di atas singgasana dikelilingi oleh para mentri. Menurut Driyakara, bersemayam bukan hanya berarti 'berada di', tapi juga bertahta. Baginda bersemayam, artinya dia berdaulat, bertahta, berkuasa seakan-akan kewibawaan hadir dalam cara duduk dan berbicara sang raja yang bersemayam itu. Dapat dipastikan jiwa sebagai prinsip rohani dan badan sebagai prinsip jasmani merupakan dua unsur dalam konstruk manusia. Dengan jiwa yang bersemayam dalam badan terbentuklah manusia.

Pertanyaan apa dan siapa manusia bisa menuntaskan kegundahan unsur-unsur manusia. Jawaban yang dihasilkan menjernihkan prinsip manusia yang berupa 'apa', dan prinsip manusia yang berupa 'siapa'. Keapa-an manusia menghasilkan jawaban materi yang berbentuk badan/raga, dan ke-siapa-an manusia menghasilkan jawaban jiwa atau roh. ${ }^{10}$ Manusia tidak bisa lepas dari apa dan siapa, dengan kata lain manusia adalah siapa yang berupa apa dan apa yang berupa siapa. Manusia terdiri dari unsur rohani dan jasmani, keduanya memiliki pengaruh tatkala manusia menghadapi segala sesuatu yang bersifat jasmani. Pergerakannya ketika menghadapi hal-hal yang sifatnya jasmani, prinsip rohani naik keatas dan prinsip jasmani mampu dikemukakan dipermukaan (Driyarkara, 1980:11).

\footnotetext{
${ }^{9}$ Driyarkara, dkk. (ed), Karya Lengkap Driyarkara; Esai-Esai Pemikiran yang Terlibat Penuh dalam Perjuangan Bangsanya, 35

${ }^{10}$ Driyarkara, dkk. (ed), Karya Lengkap Driyarkara; Esai-Esai Pemikiran yang Terlibat Penub dalam Perjuangan Bangsanya, 38.
} 


\section{Aku: Kesatuan Manusia}

Konsep 'aku', dalam pemikiran Driyarkara sangatlah penting. 'Aku' mampu menjernihkan hubungan antara jiwa dan badan. Ketika manusia berbicara tentang dirinya sendiri, dia tidak bicara tentang badan ataupun jiwa, tapi sedang berbicara tentang 'aku'. Tidak dapat dipungkiri, ketika manusia berbicara tentang dirinya sendiri ia tidak lepas dari dua aspek tersebut. Hal itu dikarenakan manusia menangkap dua aspek itu ada pada dirinya sebagai akunya. Namun jika perbincangan manusia hanya mengarah pada satu aspek saja, maka tidak ada keutuhan dalam diri manusia. Idealnya, ketika manusia berbicara tentang dirinya sendiri ia dapat menyatakan aku adalah rohani dan jasmani. ${ }^{11}$

Badan tidaklah sama dengan aku. Karena aku bisa berkata ini badanku, tetapi tidak sebaliknya. Badan hanyalah bentuk kongkret dari kejasmanianku. Dengan kata lain, aku adalah badan selama aku menjadi makhluk jasmani yang kongkret. Memang terlihat ada kesamaan antara aku dan badanku. Kesamaannya terletak pada 'selama' aku menjadi makhluk jasmani. Tapi istilah itu mampu dikerucutkan lagi, 'selama' artinya badan hanya medium bagaimana caraku nampak. Badan merupakan ekspresi dari aku. ${ }^{12}$ Inti dari hubungan antara aku dan badan terletak pada kesatuan yang tidak bisa dipisahkan, namun badan bukanlah kebulatan yang ada sendiri.

Jiwa juga tidaklah sama dengan aku. Terlalu abstrak menyematkan aku kepada jiwa. Sederhananya, pengelaman asali manusia acapkali berkaitan dengan badan, sedangkan jiwa fungsinya memberikan daya ataupun kemampuan untuk menghadapi dirinya sendiri juga realitas. Barang-barang material tidak mampu melakukan itu. Maka, jiwa manusia yang memiliki sifat rohani menjadikannya sadar akan diri dan mampu mengatasi realitas. Jadi, kalaulah manusia mengatakan aku, bukan berarti badan atau jiwanya saja, badan dan kesatuan manusia itulah yang membentuk aku.

${ }^{11}$ Driyarkara, Driyarkara tentang Manusia, (Yogyakarta: Yayasan Kanisius, 1978), 12.

${ }^{12}$ Driyarkara, Driyarkara tentang Manusia, 13. 
Aku memang terdiri dari kesatuan jiwa dan badan. Namun Driyakara menggarisbawahi, bahwa manusia adalah jasmani yang dirohanikan. Dengan kata lain, roh lah yang memiliki peran aktif. Roh lah yang menjasmani. Poin ini sangat menentukan keluhuran dan kerendahan manusia sebagai pribadi. Badan menjadi citra pribadi manusia, badan akan menjadi luhur tatkala gerak-gerik ataupun aktivitasnya digunakan untuk mengabdi pada roh. Badan adalah pengejawantahan rohani manusia. ${ }^{13}$

\section{Hominisasi dan Humanisasi}

Istilah hominisasi dan humanisasi atau memanusiakan manusia muda merupakan rumusan filsafat pendidikan Driyarkara, yang mengarahkan pada proses kesadaran untuk memanusiakan manusia. Hominisasi adalah proses pemanusiaan pada umumnya. Manusia berbeda dengan makhluk lainnya, seperti binatang ataupun tumbuhan, manusia tidak akan sampai pada fase 'ke-manusiawi-an-nya' tanpa pendidikan. Lain halnya dengan binatang. Binatang tidak perlu pendidikan, karena pada hakikatnya tidak memiliki akal budi. Sedangkan humanisasi merupakan proses lanjutan setelah hominisasi. Dalam proses ini manusia mampu mencapai perkembangan lebih lanjut, realisasi diri dalam laju budaya dan ilmu pengetahuan. ${ }^{14}$ Untuk melacak ciri-ciri pendidikan yang memiliki nuansa humanis menurut Driyarkara, dapat ditemukan dalam gagasannya tentang manusia yang telah disinggung sebelumnya. Singkat kata, pembentukan manusia-manusia yang memiliki keahlian saja tidak cukup. Keahlian idealnya harus dibarengi dengan pendidikan pribadi. Dalam istilah Driyarkara, "Pintar tanpa kesusilaan hanya akan menjadi minteri (menyalahgunakan kepandaian)".

\footnotetext{
${ }^{13}$ Driyarkara, Filsafat Manusia, (Yogyakarta: Yayasan Kanisius), 16.

${ }^{14}$ Driyarkara, dkk. (ed), Karya Lengkap Driyarkara; Esai-Esai Pemikiran yang Terlibat Penuh dalam Perjuangan Bangsanya, (Jakarta: Gramedia), 265
} 


\section{Fenomena Pendidikan}

Driyarkara memandang pendidikan bukan sebagai ide; rancangan yang tersusun dalam pikiran, cita-cita yang terletak di sini ataupun di sana tanpa adanya perubahan. Melainkan sebagai realitas terbuka, dinamis, atau katakanlah sebagai aktivitas. Pendidikan adalah suatu pengembangan dan perkembangan yang aktif. ${ }^{15}$ Maka, untuk memahami gagasan tentang hominisasi dan humanisasi, Driyarkara masuk melalui fenomena pendidikan. Lebih jauh lagi, Driyarkara meletakan fenomena pendidikan sebagai objek ilmu mendidik.

Fenomena adalah kata yang berasal dari bahasa Yunani, phainomenon (phainomaia, menampakan diri). ${ }^{16}$ Artinya, fenomena adalah sesuatu yang menampakkan diri. Namun perlu diperhatikan, segala sesuatu yang menampakkan diri atau tampak, tidak direduksi hanya dalam dimensi penglihatan, hanya diartikan tampak di depan mata. Fenomena yang dimaksud Driyarkara adalah tampak di hadapan manusia; di hadapan budi, tubuh, jiwa atau katakanlah di hadapan persona. Pemahaman Driyarkara mengenai fenomena, senada dengan fenomenologi yang difahami oleh Merleau-Ponty, fenomenologi persepsi yang menitik-tekankan tubuh sebagai sebuah wahana yang mendunia. ${ }^{17}$ Kesatuan manusia yang menangkap gejala-gejala, bukan hanya terbatas pada fungsi-fungsi tertentu dalam diri manusia. Asumsi sementara, Driyarkara banyak dipengaruhi tokoh-tokoh eksistensialis yang acapkali menggunakan pendekatan fenomenologi.

Dalam kehidupan sehari-hari, manusia dihadapkan dengan relitas yang begitu kompleks, dengan warna-warni fenomena. Pertanyaannya, dari sekian banyak fenomena manakah yang dapat dikategorikan fenomena pendidikan?. Driyarkara menjelaskannya dengan sangat hati-hati. Menurut

${ }^{15}$ Driyarkara, dkk. (ed), Karya Lengkap Driyarkara; Esai-Esai Pemikiran yang Terlibat Penuh dalam Perjuangan Bangsanya, 376.

${ }^{16}$ Donny Gahral Adian, Pengantar Fenomenologi, (Depok: Koekoesan, 2010), 5.

${ }^{17}$ Donny Gahral Adian, Pengantar Fenomenologi, 97. 
Driyarkara, fenomena pendidikan adalah perbuatan yang diberi arti. ${ }^{18}$ Pada dasarnya, perbuatan memiliki sifat netral, bisa dipastikan tidak ada perbuatan yang an sich sudah memiliki muatan pendidikan. Misalnya, ayah sedang membaca. Si anak bisa katakana secara langsung bahwa ayah sedang membaca, dan rasanya mustahil mengatakan bahwa ayah sedang mendidik. Kecuali si anak memberikan arti dari perbuatan ayahnya yang sedang membaca.

Gagasan tentang memberikan arti pada setiap perbuatanfenomena pendidikan—senada dengan para eksistensialis memandang validitas pengetahuan dalam pendidikan. Berangkat dari asumsi, individu bertanggungjawab penuh atas pengetahuannya para eksistensialis selanjutnya menyatakan validitas pengetahuan yang mewarnai dunia pendidikan ditentukan oleh nilai dan arti yang didapatkan oleh setiap individu. ${ }^{19}$ Jadi, bernilai atau tidaknya perbuatan sangat tergantung pada manusia yang memandang perbutan tersebut.

Penelitian Driyarkara tidak berhenti pada fenomena pendidikan. Driyarkara menggali lebih dalam tentang gambaran dasar pendidikan atau jiwa pendidikan. Secara eksplisit, Driyarkara menggunakan pendekatan fenomenologi dalam menenentukan gambaran dasar pendidikan. Bukan hanya mengamati segala sesuatu-dalam konteks pendidikan, fenomena pendidikan—yang tersurat tapi juga yang tersirat. Sederhananya, melalui fenomena, Driyarkara mencoba menangkap noumena. Driyarkara ingin menyampaikan bahwa fenomenologi tidak berhenti dalam memandang segala sesuatu yang nampak saja, melainkan memberi arahan pada manusia untuk mencapai tingkat kesadaran dalam situasi yang kompleks. ${ }^{20}$

${ }^{18}$ Driyarkara, dkk. (ed), Karya Lengkap Driyarkara; Esai-Esai Pemikiran yang Terlibat Penub dalam Perjuangan Bangsanya, (Jakarta: Gramedia, 2006), 357.

${ }^{19}$ Gerald L. Gutek, Philosophical and Ideological Perspectives on Education, (New Jesey: Prentice-Hall, 1988), 125.

${ }^{20}$ Driyarkara, dkk. (ed), Karya Lengkap Driyarkara; Esai-Esai Pemikiran yang Terlibat Penuh dalam Perjuangan Bangsanya, (Jakarta: Gramedia, 2006), 360. 
Jiwa pendidikan, menurut Driyarkara bukanlah rumusan yang jatuh ataupun dipetik dari langit, melainkan dari realitas yang kompleks. Jiwa pendidikan adalah pemanusiaan manusia muda. Dalam konteks perbuatan mendidik, jiwa pendidikan dimaknai sebagai tindakan yang memanusiakan manusia muda, tindakan yang mengangkatnya ke taraf insani. ${ }^{21}$ Untuk sampai pada gagasan jiwa pendidikan, Driyarkara menggunakan medium pergaulan antara pendidik dan peserta didik. Driyarkara mengandaikan pergaulan sebagai ladang, yang di dalamnya tumbuh perbuatan mendidik. Hal itu dikarenakan dibalik pergaulan-yang diposisikan sebagai gejala pendidikan-terdapat hubungan resiprokal antara pendidik dan peserta didik yang dinamakan pendidikan.

Dalam menelusuri rimba pendidikan yang belum menemukan titik terang, Driyarkara menjelaskan tentang perbuatan mendidik secara lebih terperinci. Mendidik, menurut Driyarkara termasuk dalam golongan aktivitas fundamental. Artinya, perbuatan yang seolah-olah menyentuh akar kehidupan manusia, sehingga dapat merubah dan menentukan arah hidup. ${ }^{22}$ Kata kuncinya ada pada mengubah dan mentukan arah hidup manusia. Berangkat dari tergolongnya mendidik ke dalam aktivitas fundamental, maka antara pendidikan dan pelaksanaannya terdapat perbedaan. Seperti cinta dan bentuk kongkritnya, benci juga dengan bentuk kongkritnya. Singkat kata, perbuatan mendidik merupakan penjelmaan dari sesuatu.

Orang tua, sebagai pendidik mempunyai konsep tentang manusia; manusia yang baik adalah manusia yang tidak merendahkan dirinya dengan meminta-minta. Sebelum memarahi anaknya, sebagai peserta didik, tatkala si anak mengulurkan tangan sebagai tanda meminta sesuatu dari orang lain. Dari sini bisa dipahami, larangan akan meminta-minta adalah penjelmaan dari konsep manusia baik menurut orang tua. Kalau diperhatikan secara

${ }^{21}$ Driyarkara, dkk. (ed), Karya Lengkap Driyarkara; Esai-Esai Pemikiran yang Terlibat Penuh dalam Perjuangan Bangsanya, 364.

${ }^{22}$ Driyarkara, dkk. (ed), Karya Lengkap Driyarkara; Esai-Esai Pemikiran yang Terlibat Penub dalam Perjuangan Bangsanya, 358. 
teliti, Driyarkara masih mengandaikan nilai-nilai yang lahir dari budaya sebagai pijakan untuk menjalankan pendidikan secara kongkret.

\section{Pendidikan sebagai Pemanusiaan Manusia Muda}

Pertanyaan yang terbesit dalam gagasan Driyarkara tentang memanusiakan manusia muda adalah mengapa harus manusia muda? Mengapa tidak manusia secara umum yang tanpa batasan usia? Apakah manusia tua tidak perlu dimanusiakan?. Kurang tepat rasanya kalau menafsirkan manusia muda menggunakan pendekatn kuantitatif. Manusia muda memiliki usia antara sekian sampai sekian. Namun lebih tepat, menafsirkan manusia muda menggunakan pendekatan kualitatif, manusia muda adalah manusia yang belum memiliki integrasi, dalam artian manusia yang belum mencapai tarap keutuhannya. Akan lebih jelas, jika menilik kembali gagasan Driyarkara tentang manusia. Driyarkara juga memiliki pandangan bahwa mendidik adalah membentuk manusia muda sehingga ia menjadi keseluruhan yang utuh sehingga ia merupakan integrasi. ${ }^{23}$

Harus diakui bersama bahwa manusia adalah makhluk yang aneh. Manusia harus mengangkat dirinya untuk hidup dan berada sesuai dengan kodratnya. ${ }^{24}$ Lain halnya dengan kucing. Kucing sudah 'mengkucing' sejak kelahiranya, sudah kodratnya sebagai kucing tanpa harus mengangkat dirinya menjadi kucing. Jadi, manusia harus memanusiakan dirinya. Perhatikan orang gila, pada dasarnya ia memang manusia secara umum bominisasi, namun apakah dia punya hasrat untuk memanusiakan dirinya bumanisasi. Kalaulah manusia yang waras, dengan kemawasdiriannya, tatkala ia tidak punya hasrat untuk memanusiakan dirinya dengan pendidikan, maka tidak ada bedanya dengan orang gila.

${ }^{23}$ Driyarkara, dkk. (ed), Karya Lengkeap Driyarkara; Esai-Esai Pemikiran yang Terlibat Penuh dalam Perjuangan Bangsanya, 299.

${ }^{24}$ Driyarkara, dkk. (ed), Karya Lengkap Driyarkara; Esai-Esai Pemikiran yang Terlibat Penuh dalam Perjuangan Bangsanya, 367. 
Pendidikan sebagai pemanusiaan manusia muda selalu menjadi medium yang menemani pertumbuhan manusia dari bayi, bahkan semenjak dalam kandungan, untuk menjadi manusia yang mencapai integritasnya. Perlu digarisbawahi, manusia bukanlah sebatas makhluk biologis, melainkan seorang pribadi, seorang person, seorang subjek yang mengerti diri, menempatkan diri dalam situasi, mengambil sikap, menetukan arah hidupnya. Dengan kata lain, nasibnya ada pada tangannya sendiri. Itulah yang disebut oleh Driyarkara sebagai puncak dari proses yang selalu terjadi pada diri manusia. ${ }^{25}$

Berbicara tentang hominisasi tidak bisa dilepaskan dari humanisasi. Bahkan menurut Driyarkara, membincang humanisasi saja sudah cukup. Namun tidak sesederhan itu, setiap istilah memiliki konsekuensinya tersendiri. Hominisasi membincang manusia secara umum sesuai dengan kodratnya. Humanisasi berbicara tentang perkembangnya menuju tingkat yang niscaya, melalui proses yang dinamis. Tidak ada perbincangan hominisasi tanpa humanisasi, tapi tidak sebaliknya. Selanjutnya, Driyarkara menjelaskan bahwa tingkat humanisasi merupakan tingkat kebudayaan yang lebih tinggi. Manusia mampu mengakat alam menjadi alam manusiawi, tanah menjadi ladang, tumbuh-tumbuhan menjadi tanaman, barang materi menjadi alat, rumah dan lain sebagainya. Hal ini menunjukan manusia telah sampai pada taraf humanisasinya. ${ }^{26}$

\section{Globalisasi dan Implikasinya}

Pada dasarnya, globalisasi bukanlah gejala yang terjadi di abad-20 ataupun 21. Proses globalisasi sudah terjadi sejak berabad-abad silam ketika manusia berhasil mengelilingi dunia, seperti yang dilakukan oleh Marcopolo, Magellan, dan Colombus. Jadi, kemunculan globalisasi berawal

${ }^{25}$ Driyarkara, dkk. (ed), Karya Lengkap Driyarkara; Esai-Esai Pemikiran yang Terlibat Penuh dalam Perjuangan Bangsanya, 369.

${ }^{26}$ Driyarkara, dkk. (ed), Karya Lengkap Driyarkara; Esai-Esai Pemikiran yang Terlibat Penub dalam Perjuangan Bangsanya, (Jakarta: Gramedia, 2006), 369. 
dari transportasi dan komunikasi. Tujuannya tiada lain untuk memperkuat ekonomi dan memperluas skala perdagangan. ${ }^{27}$ Namun, seiring dengan kemajuan di bidang transportasi dan komunikasi, seperti penerbangan antar benua, teknologi computer, internet, dan lain sebagainya mempercepat proses perdagangan yang ingin dilakukan. Hal itu juga yang membedakan proses globalisasi dalam abad-abad yang silam.

Globalisasi, pada umumnya diartikan sebagai pemerataan atau standarisasi gagasan, baik itu dalam bidang teknologi, komersial, dan singkronisasi budaya Barat. Dalam terang interpretasi ini globalisasi disejajarkan dengan westernisasi. ${ }^{28}$ Barat menjadi aktor yang berpengaruh dalam proses globalisasi. Hal ini disebabkan, sampai pada taraf tertentu globalisasi merupakan perpajangan kepentingan nasional negara-negara industri maju, dan sampai saat ini yang dikenal dengan Negara Maju adalah Negara Barat, salah satunya Amerika. ${ }^{29}$

Globalisasi, menurut Albrow mengarah kepada keseluruhan proses yang ditempuh, dimana manusia seluruh dunia disatukan dalam perkumpulan atau paradigma yang tunggal, dalam artian masyarakat global. Sehubungan dengan 'proses' bukanlah hal yang tunggal, maka sudah sepantasnya globalisasi dipahami sebagai istilah plural. Dalam bidang ekonomi, globalisasi mengarah kepada ekonomi internasional atau bisa disebut penyebaran relasi pasar kapitalis. Dalam hubungan internasional, globalisasi mengarah kepada urusan relasi antar Negara dan pengembangan politik global. Di bidang sosiologi, lebih fokus untuk memperluas pandangan sosial yang mendunia. Dibidang budaya, fokus dalam komunikasi global dan standarisasi budaya yang mendunia semisal, Mc-donalisasi, Coca-colanisasi. Juga dalam bidang kesejarahan, globalisasi

${ }^{27}$ Shindhunata (ed.), Menggagas Paradigma Baru Pendidikan, (Yogyakarta: Kanisius, 2000), 104.

${ }^{28}$ Meenakshi Gigi Durham dan Douglass M. Kellner (ed.), Media and Cultural Studies, (USA: Blackwell, 2006), 658.

${ }^{29}$ Shindhunata (ed.), Menggagas Paradigma Baru Pendidikan, (Yogyakarta: Kanisius, 2000), 104. 
mencoba membangun tatanan sejarah yang global. Semua bidang tersebut adalah proses yang ada dalam globalisasi. ${ }^{30}$ Albrow ingin menjelaskan terdapat banyaknya unsur yang menopang terbentuknya globalisasi. Tanpa itu semua, globalisasi tidak akan eksis, dan akan keliru rasanya kalau globalisasi hanya dipandang dari satu aspek.

Selanjutnya, dari berbagai macam unsur di atas bisa dibedakan antara globalisasi sebagai kebijakan (policy) dan globalisasi sebagai proyek (project). Sepertihalnya kasus Amnesty Interational yang fokus dalam bidang standarisasi humanisme internasional, memunculkan kebijakan atas 'kepanikan global' yang disebabkan oleh Aids, ini dalah salah satu bentuk penempatan globalisasi sebagai kebijakan. Sedangkan globalisasi sebagai proyek seringkali muncul dalam permasalahan politik-ekonomi.

Sekurang-kurang terdapat dua asumsi yang mendasari proses globalisasi, pertama, sampai pada taraf tertentu subjek ataupun pelaku globalisasi adalah negara-negara industri maju, dalam artian globalisasi merupakan kepanjangan tangan atas kepentingan negara industri maju tersebut. Kedua, kekhawatiran, kecemasan akan dampak negatif dari globalisi pada umumnya dirasakan oleh negara-negara ketiga yang baru berkembang, termasuk Indonesia, yang berperan sebagai objek globalisasi. ${ }^{31}$ Ironisnya, ketergantungan Negara-negara berkembang pada Negara-negara maju baik di bidang ekonomi, teknologi, pendidikan dan lain sebagainya secara tidak sadar telah mendukung proses globalisasi itu.

Salah satu gagasan yang dibawa, atau datang bersama globalisasi adalah maraknya pertumbuhan industri kapitalisme. Logika industri atau katakanlah pasar menyatakan sesuatu itu bernilai tatkala memiliki nilai jual, dan sebaliknya. Ironisnya, logika pasar telah menyentuh sebagian atau kebanyakan institusi pendidikan, terutama di Indonesia.

${ }^{30}$ Meenakshi Gigi Durham dan Douglass M. Kellner (ed.), Media and Cultural Studies, (USA: Blackwell, 2006), 658.

${ }^{31}$ Shindhunata (ed.), Menggagas Paradigma Baru Pendidikan, (Yogyakarta: Kanisius, 2000), 103. 


\section{Komodifikasi Pendidikan}

Globalisasi membawa perubahan besar-besaran dalam arus sejarah, pembebasan, kemajuan industri dan lain sebagainya. Dunia pendidikan termasuk lini yang terkena dampak dari arus globalisasi tersebut. Indonesia termasuk negara berkembang yang menerima dampak dari arus globalisasi, terutama dalam pranata sosial yang dinamakan pendidikan. Watak industrialisasi global mewarnai model pendidikan yang ada di Indonesia, khususnya pendidikan formal. Asumsi dari sebagian pengamat, industrialisasi pendidikan saat ini sedang berlangsung di Indonesia. ${ }^{32}$

Semenjak kolonial belanda membuka sekolah-sekolah untuk kaum pribumi, pendidikan formal tidak pernah terlepas dari kepentingan politikekonomi yang berkuasa. Pendidikan formal tidak semata-mata dibangun atas tujuan mencerdaskan anak bangsa, terlebih tujuan dibalik itu terdapat kepentingan politik dan usaha untuk menguasai perekonomian. Pada saat itu, sekolah formal hanya dapat disentuh oleh anak-anak yang berasal dari golongan menengah keatas sebagai alat untuk mengukuhkan kekuasaan. Dengan harapan, anak-anak tersebut dapat mendukung kebijakankebijakan ataupun ide-ide yang ditelurkan oleh kolonial Belanda.

Embrio industrialisasi pendidikan memang sudah muncul semenjak dibukanya institusi pendidikan formal. Dewasa ini, seperti yang kita ketahui, lembaga-lembaga pendidikan di Indonesia sudah melimpah ruah. Dimulai dari sekolah kejuruan, umum, dan agama. Krisis yang dialami oleh bangsa Indonesia dalam konteks pendidikan salah satunya, siapa saja yang mampu mengisi keuangan lembaga pendidikan tertentu dialah yang layak masuk dalam institusi itu. Memang tidak sepenuhnya benar, namun sekurang-kurangnya realitas inilah yang ada dalam tubuh institusi pendidikan Indonesia.

Hukum pasar yang berlaku di antara pesaing industri, merembak sampai dalam kehidupan sehari-hari dunia pendidikan. Dalam konteks

\footnotetext{
${ }^{32}$ Shindhunata (ed.), Menggagas Paradigma Baru Pendidikan, (Yogyakarta: Kanisius, 2000), 36.
} 
perkuliahan misalnya, sesuai dengan hukum penawaran-permintaan, Fakultas atau Jurusan yang laris akan 'dianak-emaskan', misalnya ekonomi, bisnis, kedokteran, dan lain sebagainya. Sedangkan Fakultas atau Jurusan lain yang tidak memiliki nilai jual, yang jelas bidang yang akan digeluti setelah kelulusannya, memiliki potensi untuk gulung tikar karena kurang akan peminat. Dengan kata lain, Fakultas atau Jurusan yang kurang peminatnya tidak memiliki prospek yang jelas (Sindhunata, 2000:42). konsekwensi logis dari maraknya logika pasar, institusi pendidikan hanya fokus akan kuantitas anak didik bukan kualitasnya.

\section{Mengkritisi Industrialisasi Pendidikan}

Dalam mensikapi peralihan zaman yang kental akan industrialisasi, termasuk dalam bidang pendidikan, langkah awal yang harus diambil adalah kembali pada tujuan awal pendidikan, yaitu memanusiakan manusia, menjadikan manusia berbudaya. Menurut konsep filsafat pendidikan Driyarkaya, tujuan pendidikan adalah memanusiakan manusia muda. Selain sebagai langkah awal, memanusiakan manusia muda sudah selayaknya didudukkan sebagai jiwa dari pendidikan. Dengan setia akan jiwa itu, dari sudut pandang manusia secara personal, sadar akan kemanusiaannya yang unik dengan segala sifat kemanusiaan yang dimilikinya dengan sendirinya akan membangun prisai, selektif terhadap globasisa dalam bentuk industrialisasi pendidikan.

Fenomena dalam dunia kampus misalnya, mahasiswa yang sadar akan tujuan pendidikan akan peka terhadap kondisi dunia kampus. Pendidikan formal yang dijadikan gengsi, kelas sosial, dan hanya tempat untuk merealisasikan arogansi diri adalah sebagian realitas yang akhir-akhir ini lumrah dalam kehidupan mahasiswa. Mahasiswa yang menjadikan tujuan pendidikan sebagai destinasi yang harus ditempuh melalui berbagai proses, tidak akan terjerumus untuk mengikuti arus. Sebaliknya, dia akan sadar bahwa kondisi itu tidak mengindahkan pendidikan, malah mencederainya. 
Sedangkan dari institusi pendidikan sendiri, sadar akan pemanusiaan manusia akan mengarahkan segala system yang terdapat didalamnya kepada pemenuhan tujuan tersebut. Institusi pendidikan tidak akan dijadikan ajang persaingan pasar dengan jargon-jargon menjanjikan, namun lebih kepada fokus akan perkembangan peserta didik hingga sampai pada tahapan manusia yang memiliki integrasi dan sadar akan tanggung jawabnya sebagai peserta didik. Hukum penawaran dan permintaan yang layaknya digunakan untuk pasar tidak akan mengakar dalam dunia pendidikan. Dosen contohnya, sebagai agen yang mewakili institusi pendidikan, tidak akan menggunakan logika pasar untuk mata kuliahnya dengan menawarkan mata kuliah yang mudah dengan iming-iming nilai yang menjanjikan, agar mahasiwa tertarik mengikuti kuliahnya. Hal semacam itu tidak perlu terjadi, kalau dosen mendudukan mahasiswanya sebagai manusia yang memerlukan bimbingan bukan sebagai konsumen.

Melalui gagasan Driyarkara, peralihan zaman-terutama dalam bidang pendidikan—sekurang-kurangnya akan dipandang sebagai perbuatan, yang selanjutnya diberi makna ataupun nilai. Sehingga dapat dikategorikan perbuatan mendidik. Realitas yang begitu kompleks, diseleksi sedemikian rupa, sampai pada kesimpulan bahwa realitas yang ada dihadapan manusia adalah fenomena pendidikan yang mendukung perkembangan. Driyarkara juga tidak lupa akan nilai budaya lokal yang menjadi nilai untuk melindungi diri dari pengaruh negatif globalisasi. Dalam menanggapi perkembangan ilmu alam yang saat ini menjadi primadona globalisasi, Driyarkara menawarkan gagasan "Pintar tanpa kesusilaan, hanya akan menjadi minteri (menyalahgunakan kepandaian)". Basis moral sebagai landasan perkembangan ilmu alam yang dipelajari oleh peserta didik agar peserta didik bijak dalam penggunaannya.

Selanjutnya, untuk mengkritik industrialisasi pendidikan dapat meminjam gagasan eksistensialis yang hampir senda dengan Driyarkara, manusia adalah poros perkembangan. Sistem pendidikan yang menerima dampak dari industrialisasi pendidikan, sedikit banyaknya telah mengebiri 
kebebasan peserta didik untuk memilih medium yang berguna bagi perkembangannya. Minat dan bakat pun didikte oleh sistem pendidikan tersebut. Seakan-akan sistem menjadi dewa yang tidak bisa digantikan. Dalam terang pendidikan eksistensialis yang perlu diperhatikan bukanlah sistem yang dijalankan namun yang idealnya menjadi poros adalah manusia sebagai subjek, dengan alasan kehidupan manusia yang kompleks dan individu yang varian tidak dapat diarahkan melalui sistem-sistem tertentu. ${ }^{33}$

\section{Penutup}

Perubahan zaman dengan segala muatan yang dibawanya memang tidak dapat dihindarkan. Kita tidak bisa menyebutnya keniscayaan, namun sederhananya kemajuan akan terus berjalan seiring dengan perkembangan kecerdasan manusia. Globalisasi tidak selamanya negatif. Manusia mampu mempergunakan produk dari globalisasi secara bijak, termasuk dalam dunia pendidikan. Hal itu tidak akan terealisasi tanpa disadari akan adanya unsur negatif yang melekat dalam globalisasi. setelah menyadari akan hal itu, tugas manusia adalah mencari solusi untuk mengatasinya. Salah satunya dengan gagasan memanusiakan manusia muda yang digagas oleh Driyarkara. Menyadari akan kemanusiaan dan juga kekhasan yang dimiliki oleh setiap manusia, menyadari akan tingginya nilai budaya akan menjadi mediaum menjaga diri dari pengaruh negative arus globalisasi.

Industrialisasi pendidikan yang saat ini merongrong setiap institus, tidak boleh diacuhkan. Harus ditanggapi melalui kritik-kritik dan juga saran untuk memenuhi tujuan pendidikan sehingga tercapai kehidupan sosial yang ideal. Logika pasar hanya cocok digunakan untuk produksi, sedangkan manusia bukanlah barang yang bisa di produksi. Dalam dunia pendidikan sudah selayaknyalah manusia dipandang sebagai subjek dalam realitas yang terus berkembang. Tidak ada hukum yang mampu mengeneralisir perkembangan manusia, selalu ada aspek-aspek parsial yang tidak dapat

${ }^{33}$ Gerald L. Gutek, Philosophical and Ideological Perspectives on Education, (New Jesey: Prentice-Hall, 1988), 118. 
dihukumi. Selain untuk mengkritisi industrialisasi pendidikan, gagasan Driyarkara juga mampu menjawab tantangan reifikasi-kesuksesan hanya dinilai atas materi-dalam pendidikan. Pertanyaan-pertanyaan yang memiliki konotasi materil setidaknya akan terjawb oleh gagasan itu.

\section{Referensi}

Adian, Donny Gahral. Pengantar Fenomenologi. Depok: Penerbit Koekoesan, Depok 2010.

Driyarkara. Driyarkara tentang Kebudayaan. Yogyakarta: Penerbit Yayasan Kanisius, 1980.

. Filsafat Manusia. Yogyakarta: Penerbit Yayasan Kanisius, 1969.

. Driyarkara tentang Manusia. Yogyakarta: Penerbit Yayasan Kanisius, 1978.

, Sudiarja, Budi Subanar, Sunardi dan Sarkim (editor). Karya Lengkap Driyarkara; Esai-Esai Pemikiran yang Terlibat Peneuh dalam Perjuangan Bangsanya. Jakarta: Gramedia, 2006.

Durham, Meenakshi Gigi dan Douglass M. Kellner (editor). Media and Cultural Studies. USA: Blackwell, 2006.

Gutek, Gerald L. Philosophical and Ideological Perspectives on Education. New Jesey: Prentice-Hall, 1988.

Hardiman, F. Budi. Melampau Postivisme dan Modernitas. Yogyakarta: Penerbit Kanisius, 2003

Supartono, Suparlan. Filsafat Pendidikan. Jogjakarta: Ar-Ruzz Media, 2008.

Shindhunata (editor). Menggagas Paradigma Baru Pendidikan. Yogyakarta: Penerbit Kanisius, 2000. 